\title{
CO-TEXT AND RECEPTIVE MULTILINGUALISM - FINNISH STUDENTS COMPREHENDING ESTONIAN
}

\author{
Pirkko Muikku-Werner \\ University of Eastern Finland
}

\begin{abstract}
This paper will offer some examples to explain the understanding of closely related languages. The traditional contrastive research in studying Estonian and Finnish has above all been based on similarities which have been studied on the level of, e.g., morphemes. However, resemblance is actually more holistic in nature. A rather new perspective on the intelligibility of closely related languages is that of receptive multilingualism. It refers to such communication where speakers use their L1s and understand the L1s of others. Common elements are often recognized in texts as well: cognates facilitate reading comprehension. The results of various translation tests show that the perceived similarity leads to different comprehension results in single items and in texts. Semantic relationships in phraseological units should also be considered and possibilities of improving mutual intelligibility by utilising semantic regularities will be discussed.
\end{abstract}

Keywords: similarity, receptive multilingualism, related languages, Estonian, Finnish, intelligibility, translation tests

DOI: http://dx.doi.org/10.12697/jeful.2014.5.3.05

\section{Introduction}

Europe is the home of a great variety of languages, and accepting and appreciating such linguistic diversity is a core European value. The European Commission recommends that all Europeans learn at least two languages other than their mother tongue, L1 (EU). In addition, the growing mobility of populations has led to a lasting change from monolingual to multilingual teams of people working together and to the need for communication techniques between people speaking different languages. Using English as a lingua franca is not always an optimal solution. Many ideas can get lost when English is chosen, for example, in business meetings, since not everybody feels equally at ease using English. Speaking our own language makes us feel more self-confident, more secure. Listening to a foreign language adds to the cognitive load, 
depending, of course, on the competence of the listener (Lüdi 2013: 140, 147, 152).

When operating in multilingual contexts there are solutions other than using a lingua franca. In a less monolingual setting, "each language opens up new vistas on reality and offers different forms of argumentation"; using several languages is profitable for knowledge. However, in order to benefit from a multilingual asset, a sound basis for internal communication has to be found (Lüdi 2013: 144).

One possibility for dealing with the problems of multilingual communication would be to resort to receptive multilingualism (RM). RM refers to a particular way of communication where speakers use their L1s and understand the L1s of the others, i.e. the mutual comprehensibility of related languages (Zeevaert and ten Thije 2007: 1). The interactants understand each other without the help of any additional lingua franca (Rehbein et al. 2012: 245). Braunmüller (2013: 219) justifiably raises the question: what supports 'the principle of least effort', the command of a lingua franca or employing previous linguistic knowledge of a closely related language? RM is a promising strategy for people with unbalanced multilingual repertoires to cope with exolingual (communication between people with asymmetrical competence) settings. However, the asymmetrical competencies of interactants have to be managed efficiently (Lüdi 2013: 144).

The RM concept has been widened to also include non-related languages. Mutual intelligibility is seen as a dynamic process which is a natural part of all multilingual communication (Rehbein et al. 2012: 253 and Verschik 2012: 268). Lingua receptiva ( $L a R a)$ is "the ensemble of those linguistic, mental, interactional as well intercultural competencies which are creatively activated when interlocutors listen to linguistic actions in their 'passive' language or variety" (Rehbein et al. 2012: 249). If LaRa is involved with typologically close languages, it is called inherent $\mathrm{LaRa}$ (genetic similarities); if it involves unrelated languages, it is called acquired LaRa because the necessary linguistic knowledge must be intentionally acquired for it to be efficient (previous, perhaps imperfect learning) (Bahtina et al. 2013: 165).

In 2007, the High Level Group on Multilingualism (HLGM) published a report indicating a lack of knowledge about the possibilities for communication in Europe afforded by receptive multilingualism (RM). While some work towards this multilingual goal has been done on other European languages, almost none has been done in regard to Finnish and Estonian. This article deals with the inherent 
mutual comprehensibility between Estonian and Finnish. It presents some preliminary test results of the project Receptive multilingualism: Mutual intelligibility of closely related languages (REMU). The Finnish-Estonian joint project aims to study the L1-based comprehension of a closely related language in writing and speech. It also seeks to provide new material for building a theory in the area of mutual comprehensibility of related languages.

The data consists of answers to translation tasks, questionnaires, and interviews as well as recorded conversations. The project is performed at the universities of Joensuu, Tallinn, Helsinki, Åbo and Jyväskylä (five researchers and two undergraduate students). The starting point of REMU research is the assumption that comprehension of closely related languages starts by noticing the rich formal and functional similarities (Ringbom 2007a: 26). Finns and Estonians rely on words or grammatical structures which resemble those in L1. However, formal resemblance is not automatically connected to semantic equivalence. A false hypothesis produces negative transfer.

One way of responding to new challenges of multilingual speech communities is RM. In Chapter 2, I attempt to briefly answer the question of how to increase metalinguistic awareness in order to facilitate understanding Estonian on the basis of one's mother tongue. I present some results of translation tests to demonstrate how perceptions of similarity vary (or do not vary) in tasks focusing on different levels of language: single words (including false cognates), unconnected sentences or coherent texts, morphological formatives and collocational strings. New challenges for REMU research are presented in Chapter 3. In Chapter 4, I discuss the future prospects to improve the mutual intelligibility of related languages.

Because of the increasing needs for multilingualism, learning a related language has recently become a tempting alternative besides learning English. In everyday communication, a partial understanding of Estonian is often sufficient. The odd unknown lexical element does not always hamper achieving the holistic idea of the spoken or written message. In reading, new words can be inferred from the context or guessed by perceiving some similarity to either L1 or some other language (L3). 


\section{Mutual intelligibility of closely related languages - some REMU results}

Most of the previous research concentrates on the comprehension or perception of the similarity of individual sounds and words in experimental settings in populations with different background variables. In pedagogical applications, the same kinds of details are emphasised. When using the Sieving in seven ways method, learners of a new language sieve through a text seven times in search of familiar material. The seven "sieves" are internationalisms, language group vocabulary, sound equivalences, spelling and pronunciation, syntactic structures, morphosyntactic elements and common prefixes and suffixes. These items are familiar since the learners know them from their own language. With practice, this process can become automatic (Klein and Stegmann 2000, EuroCom, and Hufeisen and Marx 2007: 317).

The answers of REMU research informants reveal, e.g., that the above-mentioned strategy has also been used in trying to understand an Estonian text (Kaivapalu and Muikku-Werner 2010: 82-84). However, the REMU project wants to progress in a more multi-dimensional direction: the levels of word, collocation, sentence, and text comprehension are explored and compared. REMU's pilot studies conducted by the research team justify the belief that perception is actually more holistic in nature, and the perceived similarity leads to different comprehension results in single items and in texts. The following examples are derived from translation tests in which 51 Finnish language students took part.

As expected, the results of the tests concerning separate words indicate that Estonian words which are phonologically and semantically very similar to Finnish words are easy to understand: in deciphering the noun tädi 'täti' ['aunt'] 97\% and the verb tantsida 'tanssia' ['dance'], $84 \%$ of the informants got the right answers. The more the spelling differs, the more difficult it is to infer the meaning of the word: with the words lumesadu 'lumisade' ['snowfall'] $69 \%$, herilane 'herhiläinen, ampiainen' ['wasp'] 25\% and küps 'kypsä' ['done' or 'mature'] 16\% gave the correct translations (Muikku-Werner and Heinonen 2012: 163 166). Results showing a reliance on the transparency of relatedness are consistent with those of van Beezoijen and Gooskens (2007: 256, 259, 261), who compared the mutual understanding of Dutch, Afrikaans and Frisian.

However, even great external resemblance can be misleading. Numerous 'false friends' between Estonian and Finnish are indeed 
problematic, as was predicted (see e.g. Laalo 1992: 11). Viiner 'nakki' ['frankfurter'] was translated correctly by $22 \%$ of informants but $41 \%$ decided on the wrong proposition *'viineri' [*'Danish pastry']. Töötada 'toimia, työskennellä' ['to work'] was mistakenly translated as *'töötätä' [*'to honk'] by $66 \%$ of the informants, and no correct translations were given (Muikku-Werner and Heinonen 2012: 167).

Context seemingly plays a key role in finding a suitable translation. If the assumed meaning does not fit the context, the informant attempts to continue the deciphering process. On the other hand, she or he can proceed by relying on the meaning of a word which has been recognized, e.g. a false friend. The remaining elements are forced to form a logical continuation of the sentence. The word viisi in "Selle viisi on loonud Pacius" 'Tämän sävelmän on luonut Pacius' ['This melody was created by Pacius.'] will be rephrased on the basis of the false friend 'viisi' [*'five']: *'Kello viisi on lounas' [*'Lunch will be served at five o'clock']. Since there is no coherent text providing thematic support for inferring the meaning of viisi 'five', the informant ignores the composer Pacius in order to create a reasonable utterance. Loonud 'created' has some resemblance with the Finnish 'lounas' ['lunch'], which makes the translation somewhat logical (Paajanen and Muikku-Werner 2012: 229-230).

If the informants are acquainted with a coherent text, they are able to draw support from a wider context. If they have previous knowledge of the subject matter or shared knowledge on a more general level, they are able to utilise it.

(1) Soome ja Eesti pealinnu eraldab teineteisest vaid kitsas riba Soome lahte.

'The capitals of Finland and Estonia are separated from each other only by the narrow strip of the Gulf of Finland.'

Omission was one of the frequently used translation strategies of the informants (Muikku-Werner 2013: 231):

(2) Suomen ja Viron erottaa toisistaan vain pieni Suomenlahti.

'Finland and Estonia are separated only by the small Gulf of Finland.'

Most translations were appropriate even though some words were omitted, like riba 'strip', which is not understandable on the basis of Finnish and kitsas 'narrow', which is a false friend; the 'false' meaning 'miserly' would not have made any sense in the utterance. 
The claim that words are easier to understand in context than outside it sounds trivial. However, we need more detailed information: which words are simple even without a context? The occasional visitor to Estonia also encounters words without contexts, e.g. in shops and in some signs, and therefore the ability to recognise unconnected phrases is useful. It is also valuable to understand why the context does not always facilitate the deciphering process. There are instances in which even similarity does not help comprehension. Rection (case government) is one of them. It can be defined as the determination of the form of one word by the presence of another word in a phrase or sentence. The co-occurrence of words with particular grammatical categories represents colligation (see Firth 1957: 181 and Jantunen 2009: 359). Hoey (2000: 234) defines colligation as "the grammatical company a word keeps and the positions it prefers; in other words, a word's colligations describe what it does grammatically".

When rection of an Estonian word differs from the Finnish one, even a familiar lexical item can cause translation problems. Rection is independent of the semantic quality of the complement, so the case form required of the complement is arbitrary.

(3) Lisaks Soomele ja Eestile on maailmas vaid üks riik, mille riigikeel kuulub soomeugri keelerühma: Ungari.

'In addition to Finland and Estonia there is only one state in the world, the official language of which belongs to the Finno-Ugric language group: Hungary.'

The Estonian word lisaks collocates with its complements in the allative case whereas the Finnish lisäksi demands the genetive as rection. Jantunen and Brunni (2012: 77) have observed that such morphological priming is common when a word is frequently encountered in certain morphophonological forms. The lack of the genitive form, which would be predictable on the basis of Finnish, creates difficulties.

(4) *Lisäksi Suomella ja Eestillä on maailmassa vielä yksi kieli, -*'In addition Finland and Estonia have in the world still one language, --

The informant seems to assume that the Estonian ending -le (allative case) is equivalent to Finnish -lla (adessive case), which can be used to form a possessive construction. The claim that Finland and Estonia have a language is not very rational. 
I have above described a situation in which there is hardly any choice when combining a collocational string, and in that case, differences between Estonian and Finnish can cause problems. However, there is another side to the coin: limited options can have a positive influence on comprehension. Firth ([1968]1957: 179) notes: "You shall know the word by the company it keeps!" Sinclair defines collocations as "the occurrence of two or more words within a short space of each other in a text" (Sinclair 1991: 170) and states that "words enter into meaningful relations with other words around them" (Sinclair 1996: 71). When recognizing one word, it is sometimes simple to guess the unfamiliar word frequently occurring with it, that is, its collocate. If there are very few alternatives for combination, this limitedness can facilitate inferring the meaning of the collocate. We probably unconsciously take into account the collocates of a word (Hoye 2007: 8). An interesting question is whether it is possible for the L1-speaker to transfer his or her assumptions about co-occurrence preferences to L2 and whether these assumptions help to understand an unfamiliar word in a collocational string.

The following example illustrates a collocation with very restricted co-occurrence: the sequence of anti uus nimi, in which anti means 'was given', 'uusi' new and 'nimi' name.

(5) Sellele [Suomen Kulttuurikeskus] anti uus nimi.

'It [the Institute of Finnish Culture] was given a new name.'

The Estonian word sellele 'to it' is confusing because its similarity to Finnish 'sille' is not obvious. In Finnish, the verb form anti could be related to the phonologically similar noun meaning 'offering', but interpreting it as such would leave the sentence without a predicate. The deficient structure of the remaining clause would probably prevent that solution and the deceptiveness of the 'false friend' would be averted.

Although anti would correctly be perceived as a verb form, one might still assume that the shorter Estonian word in comparison with the Finnish longer equivalent annettiin could mislead the translator. However, most informants translated this sentence correctly.

(6) Sille [Suomen Kulttuurikeskukselle] annettiin uusi nimi.

On the other hand, it is rather difficult to find other options than to give or to get a name; the number of potential collocates is thus restricted. 
(7) Nimi muutettiin myöhemmin --

(8) - - nimi vaihdettiin

'The name was changed later --'

In Examples 7 and 8 the translators using the verbs muutettiin and vaihdettiin (both 'was changed' in English) instead of annettiin ('was given') convey the same substance.

(9) - - sai myöhemmin nimekseen Suomi-instituutti.

' - - got later the name Finnish Institute.'

In Example 9, there is an interesting shift: in Examples 6, 7 and 8 the passive verb forms require active - albeit unknown - actors, which now have been omitted. In spite of this difference in tone, the basic meaning remains the same. The verb sai 'got' makes the content of the clause sound positive: getting something is beneficial, the name change refers to favourable incidents.

The results presented in this chapter indicate that, when trying to understand Estonian, the Finnish language students utilise the similarity of the forms and words. However, this resemblance does not guarantee comprehending the meaning, nor is it required. Due to these facts, in addition to similarities other variables, e.g. co(n)text, have also to be considered.

\section{New challenges, new directions}

In our mother tongue, we have good access to options or sets of choices to convey meaning in context; the language works as a system for meaning potential. In Halliday's systemic-functional theory, metafunctions are used to describe how this system is organised to express different functions of utterances. One of the metafunctions is the textual metafunction. Thematically, it is important that language offers means for constructing texts. Language creates coherent texts, not just arbitrary groups of sentences, and relates our message to the surrounding text. This system, which consists of the relationships between the utterances, contributes to the understanding of the meanings (Halliday 1973: 42-44 and 1978: 39-41, 192, and Thompson 1996: 28).

In understanding a closely related language, linguistic knowledge of any kind is of great significance (Hufeisen and Marx 2007: 308 and 
Singer 2007: 343). It is often connected with lexicon and word forms, but it is also linked to the textual metafunction. Text or text sequences occur in a certain co(n)text in which linguistic items can be chosen and combined in different ways. When reading an L1 text, readers do not generally pay much attention to whether the utterances in the text are consistent. If, however, the incongruity of the items is too marked, they consider the text unusual, even unacceptable. It is probable that certain textual qualities are required of texts written in languages other than $\mathrm{L} 1$, and the assumed thematic coherence can be expected to affect the conceptualization of the content.

Linguistic choices made by writers are governed, e.g., by the semantic repertoire furnished by the linguistic system. In particular, a text in which at least one constituent links sentences or lexical items to their textual environment is called coherent and cohesive. Lexical cohesion especially helps to achieve unity in texts. Linked constituents have something in common, a shared semantic feature, like summer and winter in regard to the concept of 'season' (Enkvist 1975: 32-37, 42-45, and Halliday and Hasan 1976: 332).

In order to understand the mechanisms of meaningful connections between lexical items, the concept of priming is useful. This is a term referring to the effect caused by the repeated experience of a stimulus. It may occur at several levels of linguistic structure, notably lexical and syntactic, but also at the semantic level. The most usual priming is lexical (Hoey 2007: 8).

There have been numerous experiments in which students have to decide whether two simultaneously presented strings of letters were both 'real' words (e.g. table - grass) or not (e.g. marb-bread). If the word-pairs were semantically related, the responses to them were faster than to the unrelated pairs. This phenomenon is called semantic priming: "The priming is produced by true relations of meaning, as exists, for instance, between the concepts dog and goat (both are mammals, are domesticated, have fur, etc.)". Semantic priming can be used as a tool of word recognition, sentence and discourse comprehension (McNamara 2005: 3-4).

The presented word, the "prime", can activate other words from the same semantic field (McNamara 2005: 11, 18). This activation is a form of retrieval from the semantic memory: words that go together make association possible (Pace-Sigge with references 2013: 162). In the RM context, I assume that different semantic relationships between words can be utilised to recognize one word of a cohesive unit if the other 
word is familiar. In the sentence Sellel pildil on minu ema ja õde, 'in this picture there are my mother and sister', the coordinated subjects were translated by many informants as 'mother and father'. Ema is recognizable on the basis of the Finnish word emä, nowadays 'dam', earlier also 'female parent'. In order to find the meaning of õde 'sister', the informants incorrectly used the reference to the semantic category of parenthood, not the more general level, family membership, as the starting point of their inference process. Of course, mother collocates more frequently with father than sister, which makes their solution rational. On the other hand, nobody translated õde as 'a dog' (Paajanen and Muikku-Werner 2012: 245).

The qualities of semantic relations are not bound to the affinity of Estonian and Finnish, but the question concerns some universal "regularities". In order to foster this understanding, the possibility of utilising semantic priming in inferring meanings needs to be tested. In the following examples the recognizable (on the basis of Finnish cognates) primes are in bold face, the linked words italicised.

There are many different semantic links between words:

a) same semantic field:

Sellel pildil on minu ema ja isa, $\rightarrow$ vend ja õde.

'In this picture there are my mother and father, $\rightarrow$ brother and sister.'

b) hyponymy:

Potis kasvab üks hüatsint. See on ilus $\rightarrow$ lill.

'In the flowerpot grows a hyacinth. It's a beautiful $\rightarrow$ flower.'

c) schematic implication:

Kohe on jõulud käes! Siis saame $\rightarrow$ kingitusi.

'Soon it will be Christmas. Then we will get $\rightarrow$ presents.'

d) two or more co-ordinated co-hyponyms of some semantic category:

Ma armastan roose ja $\rightarrow$ tulpe.

'I like roses and $\rightarrow$ tulips.'

e) antonymy:

See raamat on kallis, see on $\rightarrow$ odav .

'This book is expensive, that is $\rightarrow$ cheap.' 
f) cause-consequence:

Ta on rase. $\leftarrow$ Laps sünnib juulis.

'She is pregnant. $\leftarrow$ The child will be born in July.'

I assume that if one or the other connected item in the Estonian text is a cognate with the Finnish, one word could be inferred on the basis of semantic priming. If the hüatsint has been mentioned, one can decide on the hyponym lill, even though it is not familiar on the basis of Finnish. Finding the correct meaning is dependent on universal knowledge, in which some metalinguistic conceptions of cohesive and coherent texts, the character of referential relations as well the structure of semantic fields are included. When the languages involved are related, the meaning of a cohesive sequence can be found on the basis of the connected, familiar words by inference, especially when the combination appears frequently in a neutral register (for pedagogical applications, see Nesselhauf 2003: 238). All in all, the semantic dimension of inferring meaning must be tested using translation tests combined with the think-aloud procedure. A large amount of material is necessary to prove the positive influence of semantic-cohesive links on the comprehension of the related language.

\section{Discussion}

Recent research in closely related languages has emphasised the effects of phonetic proximity and similarity of vocabulary on intelligibility (see e.g. Gooskens 2006 and 2007). Similarities have also been studied in a quite atomistic fashion, on the level of morphemes or inflectional forms. However, resemblance does not always guarantee comprehending the meaning. The multi-aspect clearly occurs in the utilisation of various linguistic and meta-linguistic repertoires and world knowledge. Specific information about the subject may also contribute to intelligibility (Ringbom 2007b: 15 and Kaivapalu and Muikku-Werner 2010: 84). Less attention has been paid to collocations and other combinations, such as "semantic units". In the next phase of our REMU-project we shall attempt to determine the possibility of benefitting from this kind of approach. These new dimensions also have some common notions related to $L a R a$ : in addition to inherent similarity (see Bahtina et al. 2013: 165), a more "universal" similarity should be considered. Resemblance is not completely dependent on a close relationship between languages; it is by nature more general, e.g. textual. 
For the Finns who have not been taught Estonian, the results of REMU studies will be directed at helping them to comprehend simple Estonian texts and speech. In more formal classroom settings, learning and teaching, e.g. the collocational constraints of the words are not easy to grasp (Gass and Selinker 1994: 288). Still, language teaching materials and language teachers can provide essential shortcuts to primings (Hoey 2005: 185ff). Learning results improve when learners are conscious of similarities and differences. Knowing some universal, thus predictable, regularities of semantic "combinations" could also be useful.

Most RM research has been interested in practical interactional issues, but perspectives from the disciplines of second language learning and teaching have also been present, particularly those in the EuroComDidact projects (Klein and Stegmann 2000 and Hufeisen and Marx 2007). An EuroComFin programme similar, for example, to EuroComRom (Klein and Stegmann 2000), which provides tools for reading closely related languages, could be built on the results of the REMU-project. In conclusion, some results can later be applied to compiling teaching materials and dictionaries, which now concentrate on differences rather than similarities. Occasional language users can be provided with quick, net-based help for enhancing their strategies for communicating in a closely related language.

In the future, similar tests to those described in this article will also be conducted among Estonian-speaking learners of Finnish. Finnish and Estonian differ typologically from the languages already studied. Theoretical claims about the effects of similarity on comprehension can thus be tested with a pair of closely related non-Indo-European languages. Furthermore, it is possible to extend such research to smaller related languages in danger of extinction (Karelian, Livonian), thus improving their opportunities to survive.

\section{Acknowledgements}

I would like to thank the two anonymous reviewers for their valuable comments.

\section{Address:}

Pirkko Muikku-Werner

University of Eastern Finland

P.O.B. 111

FI-80101 Joensuu

E-mail: pirkko.muikku-werner@uef.fi 


\section{References}

Bahtina, Daria, Jan D. ten Thije, and Frank Wijnen (2013) "Combining cognitive and interactive approaches to lingua receptiva". International Journal of Multilingualism 10, 2, 159-180.

Braunmüller, Kurt (2013) "Communication based on receptive multilingualism: advantages and disadvantages”. International Journal of Multilingualism 10, 2, 214-223.

Enkvist, Nils Erik (1975) Tekstilingvistiikan peruskäsitteitä. Helsinki: Gaudeamus.

$\mathrm{EU}=$ The EU internet handbook. Available online at $<\mathrm{http}$ ://ec.europa.eu/ipg/content/ multilingualism/policy/index_en.htm>. Accessed on 08.04.2014.

EuroCom $=$ EuroCom: The way to European multilingualism . Available online at $<$ http://www.eurocomresearch.net/kurs/englisch.htm>. Accessed on 08.04.2014.

Firth, John Rupert (1957) Papers in linguistics 1934-51. Oxford: Oxford University Press.

Firth, John Rupert ([1968] 1957) “A synopsis of linguistic theory, 1930-55”. In Frank Robert Palmer, ed. Selected Papers of J. R. Firth 1952-59, 168-205. London: Longman.

Gass, Susan M. and Larry Selinker (1994) Second language acquisition. Hillsdale: Lawrence Erlbaum.

Gooskens, Charlotte (2006) "Linguistic and extra-linguistic predictors of inter-Scandinavian intelligibility". Linguistics in the Netherlands, 101-113.

Gooskens, Charlotte (2007) "The contribution of linguistic factors to the intelligibility of closely related languages". Journal of Multilingual and Multicultural Development 28, 6, 445-467.

Halliday, Michael A. K. (1973) Explorations in the functions of language. London: Edward Arnold.

Halliday, Michael A. K. (1978) Language as a social semiotic. London: Edward Arnold.

Halliday, Michael A.K. and Ruqaiya Hasan (1976) Cohesion in English. London: Longman.

HLGM $=$ High Level Group on Multilingualism . Final report. 2007. Comission of the European Communities. Available online at $<\mathrm{http}$ ://ec.europa.eu/languages/documents/doc1664_en.pdf $>$. Accessed on 08.04.2014.

Hoey, Michael (2000) Textual interaction. London: Routledge.

Hoey, Michael (2005) Lexical priming. A new theory of words and language. London: Routledge.

Hoey, Michael (2007) "Lexical priming and literary creativity". In Michael Hoey, Michaela Mahlberg, Michael Stubbs, and Wolfgang Teubert, eds. Text, discourse and corpora. Theory and analysis, 7-29. London: Continuum.

Hufeisen, Britta and Nicole Marx (2007) "How can DaFnE and EuroComGerm contribute to the concept of receptive multilingualism?" In Jan D. ten Thije and Ludger Zeevaert, eds. Receptive multilingualism. Linguistic analyses, language policies and dialectic concepts, 307-321. Amsterdam: John Benjamins.

Jantunen, Jarmo (2009) “"'Minulla on aivan paljon rahaa” - Fraseologiset yksiköt suomenkielen opetuksessa”. Virittäjä 3, 356-381. 
Jantunen, Jarmo and Sisko Brunni (2012) "Morfologinen priming ja fraseologia vieraan kielen oppimisessa: korpustutkimus oppijansuomesta”. Lähivõrdlusi. Lähivertailuja 22, 71-100.

Kaivapalu, Annekatrin and Pirkko Muikku-Werner (2010) "Reseptiivinen monikielisyys: miten suomenkielinen oppija ymmärtää viroa äidinkielensä pohjalta?” Lähivõrdlusi. Lähivertailuja 20, 68-97.

Klein, Horst G. and Tilbert D. Stegmann (2000) EuroComRom - Die sieben Siebe: Romanische Sprachen sofort lesen können. Aachen: Shaker Verlag.

Laalo, Klaus (1992) Huvitav lugu - kiinnostava juttu. Suomen ja viron välinen sanaston riskiryhmä ja sen tausta. Helsinki: Suomalaisen Kirjallisuuden Seura.

Lüdi, Georges (2013) "Receptive multilingualism as a strategy for sharing mutual linguistic resources in the workplace in a Swiss context". International Journal of Multilingualism 10, 2, 140-158.

McNamara, Timothy P. (2005) Semantic priming. Perspectives from memory and word recognition. New York: Psychology Press.

Muikku-Werner, Pirkko (2013) "Vironkielisen tekstin ymmärtäminen suomen kielen pohjalta”. Lähivõrdlusi. Lähivertailuja 23, 210-237.

Muikku-Werner, Pirkko and Maria Heinonen (2012) "Lumesadu - 'tarina' vai 'lumikasa' vai ei kumpikaan? Suomalaiset lukiolaiset viron sanoja tunnistamassa”. Lähivõrdlusi. Lähivertailuja 22, 157-187.

Nesselhauf, Nadja (2003) "The use of collocations by advanced learners of English and some implications for teaching". Applied Linguistics 24, 2, 223-242.

Paajanen, Ilona and Pirkko Muikku-Werner (2012) “Tee on kitsas - onko 'tee kitkerää' vai oletteko 'te saita'? Suomalaiset opiskelijat viroa ymmärtämässä’. Lähivõrdlusi. Lähivertailuja 22, 219-258.

Pace-Sigge, Michael (2013) "The concept of Lexical Priming in the context of language use". ICAME Journal 37, 149-173.

Rehbein, Jochen, Jan D. ten Thije, and Anna Verschik (2012) "Lingua receptiva (LaRa) - remarks on the quintessence of receptive multilingualism". International Journal of Bilingualism 16, 3, 248-264.

Ringbom, Håkan (2007a) "Actual, perceived and assumed cross-linguistic similarities in foreign language learning". AFinLAn vuosikirja 65, 183-197.

Ringbom, Håkan (2007b) Cross-linguistic similarity in foreign language learning. Clevedon: Multilingual Matters LTD.

Sinclair, John (1991) Corpus, concordance, collocation. Oxford: Oxford University Press.

Sinclair, John (1996) "The search for units of meaning”. Textus 9, 75-106.

Singer, Murray (2007) "Inference processing in discourse comprehension". In M. Gareth Gaskell, ed. The Oxford handbook of psycholinguistics, 343-359. Oxford: University Press.

Thompson, Geoff (1996) Introducing functional grammar. London: Arnold

Van Beezooijen, René and Charlotte Gooskens (2007) "Interlingual text comprehension. Linguistic and extralinguistic determinants". In Jan D. ten Thije and Ludger 
Zeevaert, eds. Receptive multilingualism. Linguistic analyses, language policies and dialectic concepts, 249-263. Amsterdam: John Benjamins.

Verschik, Anna (2012) "Practicing receptive multilingualism: Estonian-Finnish communication in Tallinn". International Journal of Bilingualism 16, 3, 265-286.

Zeevaert, Ludger and Jan D. ten Thije (2007) "Introduction". In Jan D. ten Thije and Ludger Zeevaert, eds. Receptive multilingualism. Linguistic analyses, language policies and dialectic concepts, 1-21. Amsterdam: John Benjamins.

Kokkuvõte. Pirkko Muikku-Werner: Ko-tekst ja retseptiivne mitmekeelsus - kuidas soome üliõpilased mõistavad eesti keelt. Tänapäevaseid keeleoskusnõudeid arvestades on mõistlik soodustada lähedaste sugulaskeelte, nagu eesti ja soome keele õppimist. Artikkel esitab näiteid, mis selgitavad arusaamist lähedaste sugulaskeelte vahel. Retseptiivse mitmekeelsuse uuringud sugulaskeele arusaadavusest emakeele baasil lähenevad mõistmisele üsnagi uuest vaatepunktist. Retseptiivne mitmekeelsus tähendab suhtlust, kus kõnelejad kasutavad oma emakeelt ja saavad aru oma kaasvestlejate emakeelest. Selle tähtsaks eelduseks on sarnasuste ärakasutamine holistilisematelt ja mitmekülgsematelt seisukohtadelt, kui seda varem on tehtud; näiteks ei liiguta pelgalt morfeemide tasandil, nagu soome ja eesti keele kontrastiivsed uuringud tavaliselt on teinud. Sarnasus on tegelikult palju holistlikum. Näiteks tekstidest ära tuntud sarnased elemendid lihtsustavad loetu mõistmist. Soome üliõpilaste seas läbi viidud testid näitavad, et tunnetatud sarnasus viib üksiksõnade ja lausetesse paigutatud sõnade tõlkimisel erinevate tulemusteni, mis annab tunnistust ko(n)teksti olulisusest. Tähelepanu tasub pöörata ka fraseoloogilise ühendi liikmete vahelistele semantilistele suhetele. Nendevaheliste seaduspärasuste vaatlemine võib pakkuda uusi võimalusi lähedase sugulaskeele mõistmise lihtsustamiseks.

Märksõnad: sarnasus, retseptiivne mitmekeelsus, sugulaskeeled, eesti keel, soome keel, arusaadavus, tõlketestid 